Raphael M. Dayanov

Lecturer of the Architecture Department of the Repin State Academic Institute of Painting, Sculpture, and Architecture,

Architect-restorer of the highest category, Honored Builder of the Russian Federation, Honorary Architect of the Russian Federation, Honorary Restorer of St. Petersburg, Director of the Liteinaya Chast-91 Architectural Bureau e-mail: raf_dayanov@mail.ru

Saint Petersburg, Russia

Orcid 0000-0002-8950-0698

Anna M. Zalmanzon

Researcher at the Baltic Restoration Collegium, zalmanzon@mail.ru e-mail: Saint Petersburg, Russia Orcid 0000-0002-5099-4301

\title{
THE CONSTRUCTION OF THE KIROV DEPARTMENT STORE AND FACTORY-KITCHEN IN MEMOIRS AND DOCUMENTS
}

Summary: The article presents the history of the Narva Factory-Kitchen construction in the late 1920s - early 1930s. A decision was made on the general construction of factory-kitchens, which were to become the basis of the USSR's state public catering system in the 1920s-1930s. In Leningrad, it was decided to build four factory-kitchens, including the Narva one, which was supposed to share a building with a department store (later the Kirov Department Store). A competition was announced to design the factory-kitchen building. The article describes the factory-kitchen project that won the competition. Four architects were the authors of the project developed in the constructivism style. Over time, the idea of factory-kitchens turned out to be inconsistent, and the Narva Factory-Kitchen was closed.

The Kirov Department Store had also stopped working for a long time. In the early 2000s, a decision was made to reconstruct it. During the preparation of the project for the reconstruction of the Kirov Department Store, research work was carried out to identify design materials and documents on the history of the Narva Factory-Kitchen and Department Store building. In addition to many graphic images, the authors of the article discovered interesting facts about the construction progress and the first years of the factory-kitchen. The found documents: protocols, reports, critical notes, and memoirs of a participant in the events, illuminate the construction and operation of the factory-kitchen from different points of view - from official materials (texts of explana- tory notes to project documentation, publications in the official press, minutes of meetings, construction inspection reports) and from personal assessments of various facts related to the Nevsky Factory-Kitchen (memoirs of contemporaries, workers who took part in the construction work and further operation of the enterprise). The documents also made it possible to reproduce the realities of the production process of the 1920s-1930s, for example, socialist competition, high-powered work practices, and shturmovshchina. The fact that construction work was carried out in the absence of actual plans was revealed. Besides, the coordination of work was systematically disrupted. The created picture shows a low work organization level, which caused numerous imperfections and low construction quality. In turn, this was one of the reasons for the problems in the operation of the factory-kitchen. Based on the found documents and the actual violations of an operational nature, the article also notes: non-observance of the sanitary and hygienic regime, the monotonous menu of the dining room, low quality of dishes. The documents also report on economic violations. Later, for several reasons, the very idea of a factory-kitchen discredited itself. At present, the building of the Kirov Department Store has been reconstructed and is in operation.

Keywords: factory-kitchen of Narva region; the Kirov Department Store; organization of construction; the USSR history; 1930s. 


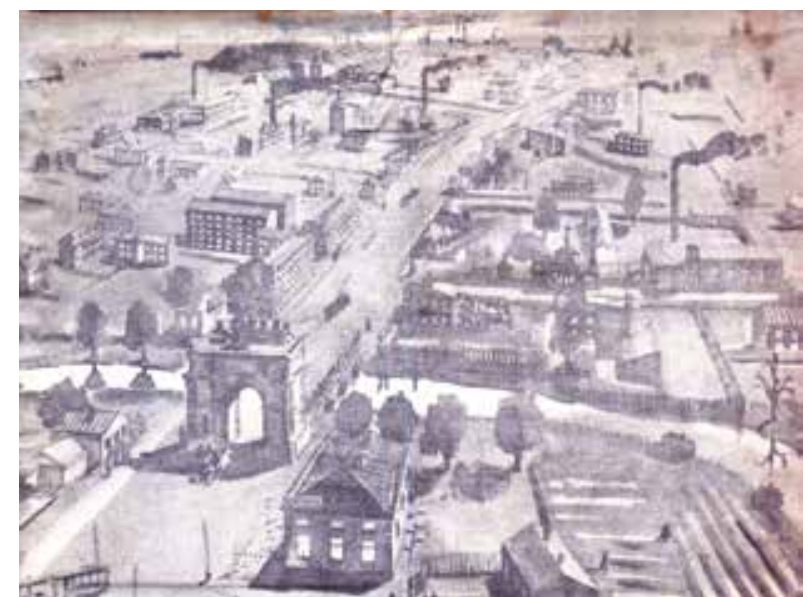

Narva Square in the 1920s. Book endpaper: "Four Generations. Narvskaya Zastava". Leningrad, 1933.

During the project's preparation to reconstruct the Kirov Department Store, research work was carried out to identify design materials and documents on the Narva Factory-Kitchen and Department Store history. In addition to many graphic images, the authors of the historical reference discovered interesting facts about the construction progress and the first years of the factory-kitchen. The following documents were found: protocols, reports, critical notes, and memoirs of a participant in the events. They illuminate the process of construction and operation of the factory-kitchen from different points of view - from official data and from an emotional assessment of what was happening. We present them in one publication to reproduce as accurately as possible the history of the Kirov Department Store and Factory-Kitchen's construction, the events associated with it, and the emotional atmosphere.

In Leningrad in 1928, a competition was announced for the design of factory-kitchens. According to the competition terms, they were supposed to supply industrial enterprises with ready-made meals and be part of the regions' public centers (St. Petersburg. Petrograd. Leningrad. Encyclopedic Reference Book. Leningrad, 1992, p.635). Young architects: A.K.Barutchev (1904-1976), I.A.Hilter (1902-1976), I.A.Meerson (1900-1941), J.O.Rubanchik (1889-1948), won the competition. They were entrusted with the design of four regional factory-kitchens.

The need to build catering establishments with a large productive capacity in workers' districts was dictated by the rapid recovery and development of industrial enterprises in the late 1920s - early 1930s. Increased many times over the decade of the 1920s, the population of the outskirts had to be provided with food. The centralized supply and processing of

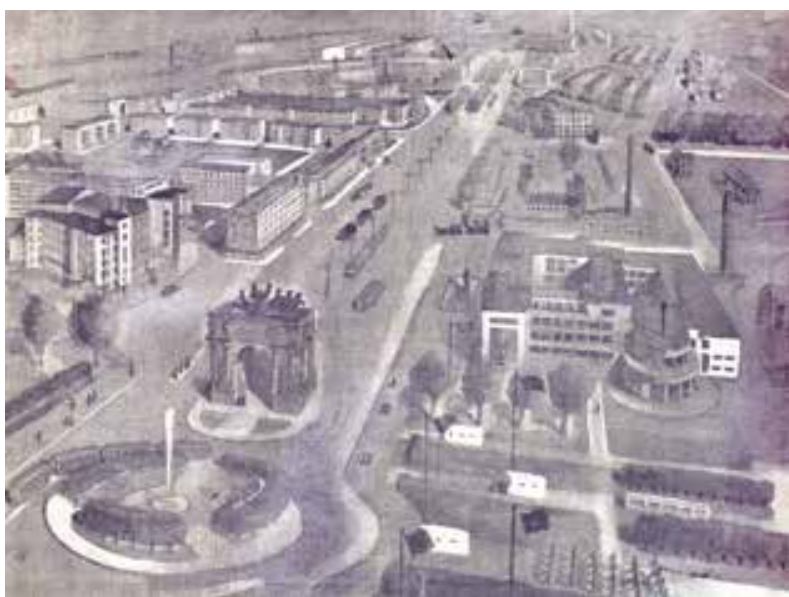

Narva Square in the 1930s. Book endpaper: "Four Generations. Narvskaya Zastava". Leningrad, 1933.

products was an urgent measure and the most rational supply scheme in those conditions. Before the Narva Factory-Kitchen's construction, the Lenin Factory-Kitchen operated in the Narva region, apparently located in a building adapted for this function.

By the beginning of the Narva Factory-Kitchen construction, the Lenin Factory-Kitchen building was in disrepair; there were plans to halt it. [5]

According to the detailed design, the Moscow-Narva Factory-Kitchen project assumed the unification of the factory-kitchen and the district department store in one building. The place allocated for the construction was located in the Moscow-Narva region's administrative and public center, which seemed convenient for the factory-kitchen and department store's functioning: visiting the canteen and shop by workers and delivering meals to the enterprises of the region. (Fig. 1. Narva Square in the 1920s. Book endpaper: "Four Generations. Narvskaya Zastava". Leningrad, 1933.) Specialists, workers of public catering, were involved in the development of the production process technology. The premises' dimensions and their location were developed in cooperation with a commission of specialists created by the Narpit Leningrad Regional Consumer Union. [8]

The equipment was designed under the standards developed by Narpit for factory-kitchens, with 12 thousand meals a day.

By March 1929, the design of the Narva Factory-Kitchen was completed. The design materials sent by the design organization for approval to the Leningrad Labor Protection Department are dated to the above mentioned time. (Fig. 2. An Explanatory Note to the Project for Constructing a Factory-Kitchen in the Moscow-Narva Region, TsGA NTD, fund 193, in. 3-1, f. 5832, sh. 7.) 


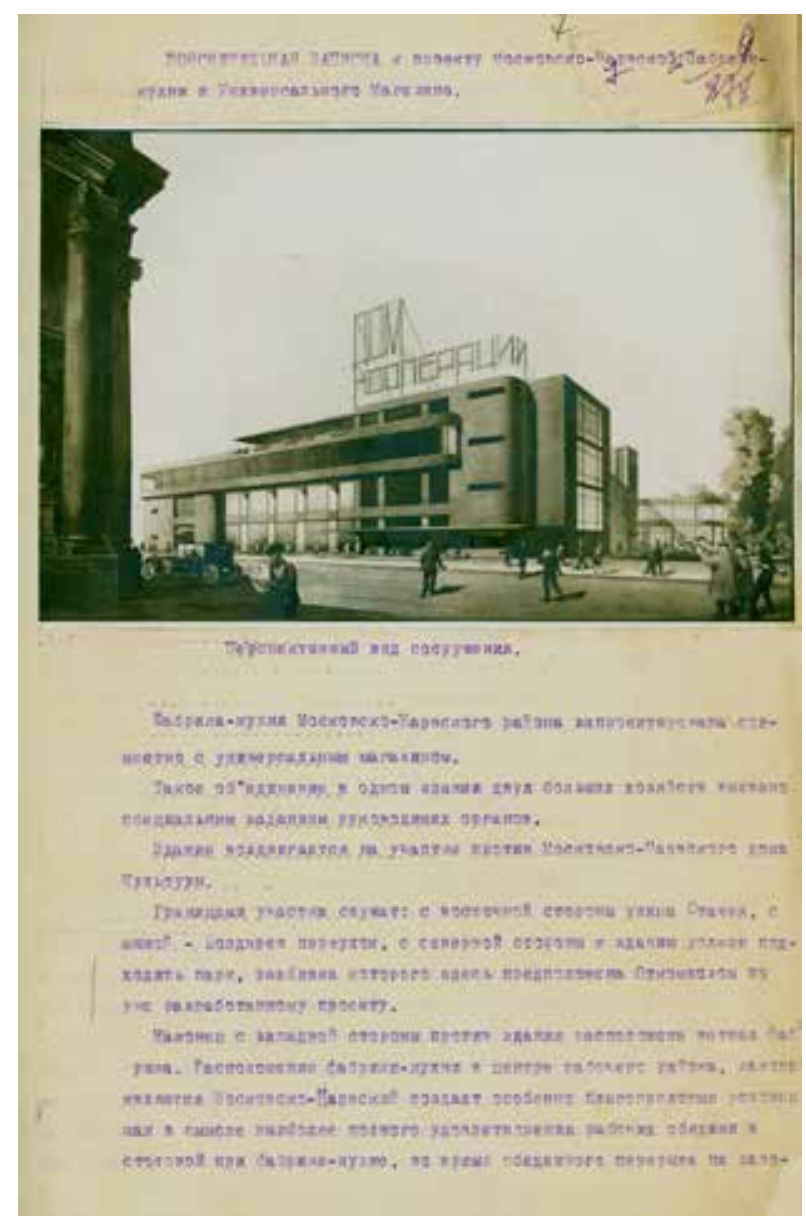

An Explanatory Note to the Project for Constructing a FactoryKitchen in the Moscow-Narva Region, TsGA NTD, fund 193, in. 3-1, f. 5832, sh. 7.

The Kirov Department Store and Factory-Kitchen is designed in the constructivism style. Constructivist aesthetics is reflected in the layout of the volumes and the plan: a combination of volumes of different shapes and heights, an asymmetrical plan composition, a dynamic expressiveness of the design achieved by shifting the masses and contrasting design of facades. In the factory-kitchen architecture, numerous techniques are used. They are characteristic of the architecture of constructivism and have a wide range of analogs in the buildings by constructivist masters close in time.

A frame system of monolithic reinforced concrete blocks was used to construct the factory-kitchen and department store building. When working on the building project with a complex function, including a developed production process, trade, and public catering, planning decisions were made based on the analysis of the diagrams of functional processes. The building layout was thought out so that the diagrams of functional processes inside it did not intersect. (Fig. 3. The Project of a Factory-Kitchen of the Moscow-Narva District. Situational Plan of the Cen-

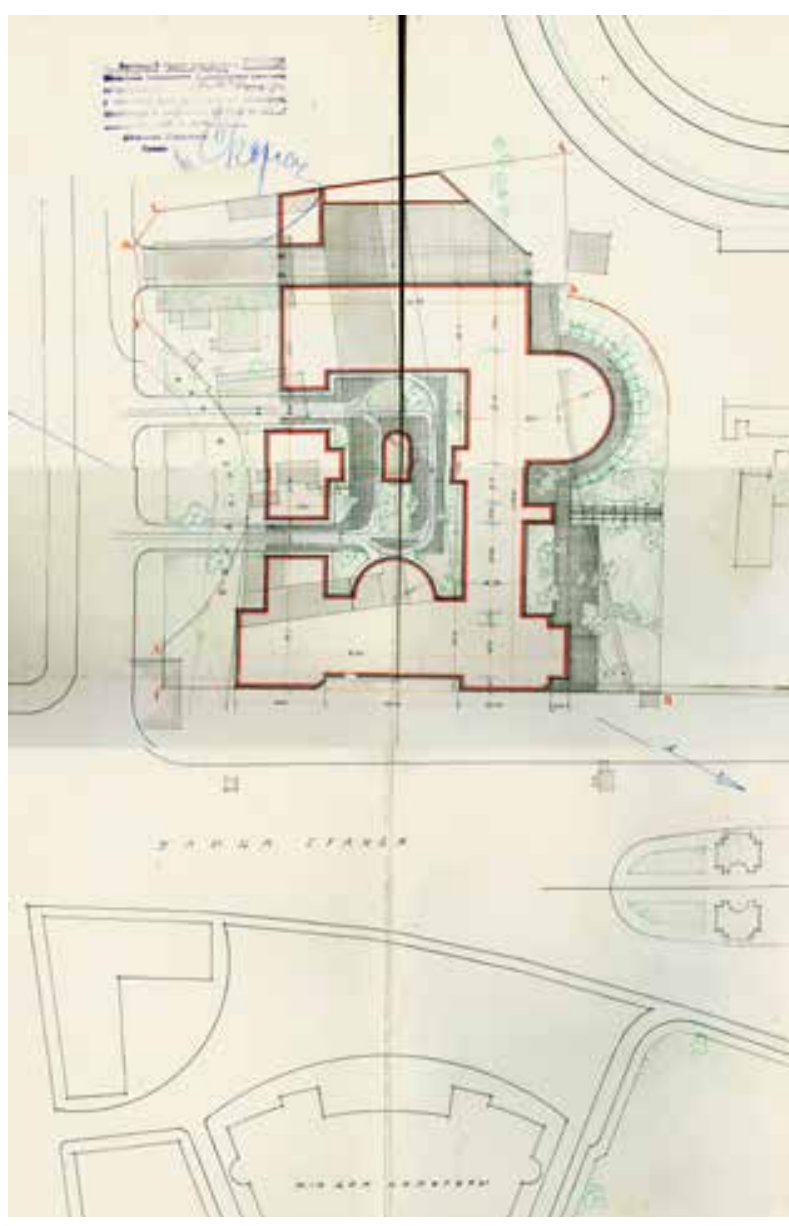

The Project of a Factory-Kitchen in the Moscow-Narva Region Situational Plan TsGA NTD, fund 193, in. 3-1, f. 5832, sh. 76

tral State Archive of NTD, fund 193, in. 3-1, f. 5832, sh. 76.). The project was approved in April 1929. [4]

The architects assumed that 190 people would work at the factory-kitchen. As construction progressed, the factory-kitchen's projected capacities and norms began to be falsified in the press. In 1930, Krasnaya Gazeta named the projected capacity of the factory-kitchen at 35-40 thousand meals a day. The number of factory workers, according to the newspaper, would be 1,500. [1]

Construction work began in May. [5] According to the leading regional organizations' instructions, the building was to be built as soon as possible. The pace of construction was accelerated by the method of socialist competition and high-powered work practices: the workers' teams overworked, worked for days. When workers became scarce, three women's construction brigades were formed. Architectural and construction plans and equipment drawings were developed simultaneously with the construction. Often the pace of construction outstripped the delivery of the plans. Sometimes the builders themselves made 
responsible decisions regarding the construction of the building and equipment. [5] The provision with equipment was carried out during the construction of the building. In winter, work was carried out in enclosures with temporary heating provided by one of the neighboring factories. [5] According to the approved schedule, the factory was to be completed by May 1,1930 . In July 1929, earthworks and concrete work were carried out at the construction site; pile driving was underway - 690 eight-meter piles and 210 eleven-meter piles were driven, which accounted for about $27 \%$ of pile work. The builders were two weeks behind schedule.

Construction plans did not keep up with the work at the construction site. The inspection report of the construction site stated: "Delay in the schedule may still increase if the working plans for buildings IIA, IB, IV basement floors, as well as for buildings I A and III second floors are not delivered to the place of work within the next four days. The organization of the work is satisfactory. $\langle\ldots\rangle$ There is a rationalization unit at the construction site, and socialist competition is held between individual groups of workers and between technical personnel within the construction site. The work is carried out in two shifts for the pile driving, earthworks, reinforcement bars, and partly for concrete work. The overall quality of work is satisfactory, no deviations from the approved USK project have been noticed." [7]

In 1930, the delay in the development of working plans continued. On March 25, 1930, the Leningradskaya Pravda newspaper published an article, "The Plans are Lying". It described the difficulties of building a factory-kitchen and the inconsistency of actions between the designers and builders. To verify the newspaper's facts, an inspection of the construction by a commission took place on April 4, 1930. The commission confirmed the newspaper's facts and concluded that the deadline for May 1, 1930, was missed. [6] The act drawn up by the commission describes situations in which the implementation of architectural projects by the builders was difficult due to the confusion with working and construction plans: "Plastering works performed on a significant plane of walls and ceilings are now unnecessary due to the use of space under the ceilings for the laying of ventilation pipes, and now covered by a false ceiling, the plastering of which is now required again. On a small part of the walls, the plaster is now being removed due to the decision to replace it with tiles with which it is being lined. All of the above altera- tions, imperfections and changes in work, etc, are explained by the lack of a general link between the main project and the projects of sanitary equipment and parts, which were completely absent during the main work. The lack of drawings for sanitary equipment during the rough work entailed all the alterations described. In the future, it will inevitably entail in those dimensions that are necessary to complete the equipment. ... The building administration's attention is drawn to the curvature of the vertical racks of metal bindings in the facade openings, causing discrepancies between the glass plane and their seats. It also indicates the lack of skew and water drainage holes on the balcony." [6] The Commission found that the delay in the timing of work was caused by the shortage of plans for the construction site: "It is the massive rework associated with the installation of equipment that is taking place. This is not done because the plans are lying. I must say that there were no plans at all when the building was made in the rough." [7]. Inspection of the construction by the head of LOUSK on July 11-12, 1930, also revealed a delay in dates and poor work quality. In particular, the inspection report noted: "the fast pace of work at the expense of its quality (poor internal plaster, poor quality roofing, deflections of reinforced concrete structures)" [7].

The new date for the completion of the factory-kitchen was set to September 15, 1930. [2] On September 20, 1930, the Leningradskaya Pravda newspaper reported that on that day, the Narva Factory-Kitchen began to supply the enterprise with hot meals. On September 25, the official opening of the factory-kitchen would take place. ... (Fig. 4. The Narva Square in the 1930s. Book endpaper: "Four Generations. Narvskaya Zastava". Leningrad, 1933.)

Vivid memoirs that were left by Stepanov, a participant in the construction, later - a worker of the factory-kitchen, supplement the official documents on the progress of the construction of the factory-kitchen: "In 1920, I joined the Komsomol. In 1922, I was promoted to a member. I worked at a factory, was in the army, was demobilized in 1928; in April 1929, I got involved in the construction of a factory-kitchen. All work proceeded under the supervision of engineer Dzhorogov. In April, we began to prepare piles, according to the project - eight-meter ones. About a thousand piles were driven in. They tested whether they could withstand such a massive building (the factory was built on the Tarakanovka River, the place here is wet, and the piles went into the ground from 
one blow, from gravity). So they tested one of the piles, it turned out that the piles were unusable: they needed eleven-meter piles. Work on their manufacture began again. These piles can easily withstand the entire mass of the building. Public organizations of the Narva region demanded the construction of the factory in the shortest possible time. By this time, problems appeared at the Lenin Factory-Kitchen. There were cracks. It had to be stopped. It served two giants - Red Putilovets and Triangle. It was necessary to develop socialist competition and high-powered work practices, and it began to be carried out from the second building.

It began between brigades, and at that time, the first Komsomol brigade was organized. There were not many of us, about twelve people. A bad opinion surrounded us! It was always said that the Komsomol brigade gets the best job. When all the buildings were ready, and the fifth fell behind, we deliberately took on it and helped with the Komsomol brigade. We, the Komsomol brigade, had to work three to four hours every evening. We did not reckon with time. The secretary of the party said: we were staying today, and we stayed. At all construction sites in winter, work was completed. In general, construction was considered seasonal work; however, at the Factory-Kitchen, it was just the opposite - work in winter did not decrease but increased even more. Heating was organized from a neighboring plant, and here, inside, work was already underway to equip the building. In 1930 , it began to be clear that the workforce was insufficient. Three women's brigades were specially organized, which worked on an equal basis with men on building walls. There was no specialty where women would not participate. The reinforcement workers were women; the concrete workers were women. Komsomol members fought for the pace. There was Grigory Abramovich Izerson, an assistant foreman, a technician. The guy spent the day and night here, rooting for the factory. The guy was simple but knew how to work. There were cases when we were waiting for the plans, but there were no plans. Take, for example, the oil tank. You need to start up the stove, but the tank is not ready. He comes to me and says: "Come on, Stepanov, we will design it ourselves because there are no plans; the factory cannot be delayed". Here we sat for five or six hours and made a plan. He tells me about the resistance of materials, and I design, draw. Then the plan came and matched ours. The same was with the staircase. No plans were sent. We thought - the factory would be built, but the main staircase would not be needed. We had to make it ourselves so that the stairs could withstand. For night control, a duty was established at the construction site. The light cavalry of our team had to spend the day and night. There were cases when gasoline was poured on purpose where people smoked. There were many cases. Or, when the department store was opening, someone brought in kerosene. Who brought the kerosene, and why was unknown. And shavings were spread around. We worked around the clock to finish the factory on time. True, we did not meet the deadline. The deadline was May 1, 1930. We opened on October $1^{\text {st". }}$ [5]

On October 3, 1930, Krasnaya Gazeta reported that on October 1, 1930, cooking equipment was put into operation at the Narva Factory-Kitchen, and the first "trial" lunch was given. [1] On this day, the first lunch was given to the workers and employees who were building the factory... (Fig. 5. Cookroom. Leningrad Factory-Kitchens // Architecture of the USSR, 1933, No. 2, p. 20.) However, the building was not entirely ready for use. Documents indicate that in October 1930, the installation of engineering systems continued. On October 12-16, 1930, an inspection of the production facilities was carried out to determine whether they were ready for launch, which established that: "The premises are not ready for operation. Plans for water supply, power supply, ventilation were not presented to the commission". The department store was opened in the spring of 1931.

In September 1931, the Moscow-Narva Factory-Kitchen was transferred from the LSPO (Leningrad Council of Consumer Societies) to the state. The factory-kitchen's planned capacity of 15 thousand meals a day was achieved in the period before 1931. Most of the population of the Moscow-Narva region received meals from the regional factory-kitchen. The Putilov plant, the Severnaya Verf, and the Molotov plant were the largest consumers. The factory-kitchen transported hot meals to its branches - buffets at enterprises. The workers of the factories closest to the factory-kitchen dined in the hall at the factory-kitchen. Children from nearby schools and kindergartens received meals here as well.

A factory-kitchen builder and worker describes its work in the early 1930s as follows: "On October 1 , the first lunch was given to the workers and employees who were building the factory, and from October 1 , five canteens were open. When the factory was put into operation, still some workshops did not start working. There were no cars. There were cases 
when the water did not pass. The yard, from which all meals should be delivered to the factories, was littered with construction waste. There was no expeditionary platform, and sometimes the carts with lunches that went to the Putilov plant had to pass a whole heap of garbage. There was no separate staircase; there were irregularities in the operation of the elevators. The department store was finished by May 1,1931 , because it was not so urgent. When the factory was being built, it was designed for fifteen thousand food units. It began to develop, reached fifteen thousand, continued. In early January 1931, the Lenin factory stopped. Our factory had to take back the rate that the Lenin factory was feeding. We began to serve thirty-five thousand. After the Lenin factory was repaired, we still did not slow down. The main consumer is the Putilov plant. At the Putilov plant, there is not a single workshop without our buffet. We supply them with products, equipment, and labor. The administration makes the canteen itself and the equipment of the plant. Severnaya Verf is the second major consumer. The third one is the Molotov plant, and then the Narva region's small factories, except for the Red Triangle and the Equality factory fed by the Lenin Factory-Kitchen. The factory works without interruption. There are no days-off, no holidays. And on November 7, the factory does not rest. If the hot shop does not work, then the cold one works. There is not a single moment for the factory to rest. We deliver food to the place in a thermos in a hot form, but we can not hide the fact that if food is poured into a thermos at noon, it can keep warm up to six or seven hours - it cools down. In general, the factory is designed for semi-finished products. Thus, there should be a kitchen on-site; we only have partially finished products. Now there is still a new method, which was invented by our laboratory assistant, Dr. Uglov, in such a way as to carry concentrated soup to the places, to the buffets, that is to say, it is transported there concentrated: after it is delivered to the place, it is diluted with hot boiling water, and the best soup is obtained in terms of calorie content and overall. One hall is assigned to those factories and organizations that are located closer to the factory, so as not to make a special buffet there so that workers can come here and eat during a break. This room is downstairs. The second hall is the green hall; it is called the public hall. Anyone who wants can dine here at a higher price. The third room (on the third floor) is called the pink room, the children's room. We serve the children of the Narva region. Pupils from schools come until two o'clock. We feed those nearby schools here at the factory; in an organized manner, they come here with the older groups, sit at the tables, and we serve them. From two o'clock, we feed children who are not yet in school. We feed the schools of the Narva region, which are far from the factory, locally. We serve all schools in our district, and not only schools but also kindergartens. The fourth hall, next to the Komsomol collective, is a service canteen. Here, those who work in the factory, except those who work on the periphery, can eat in our cafeterias. In February 1932, we had 1,750 workers, together with the Narva region's periphery, with all the buffets. The staff of our factory also includes a brigade apprenticeship. We have about forty students who are preparing for future workers here. Factory workers also attend courses. There is a room for cooking apprenticeship and advanced training. For example, this year, ordinary workers have already reached the position of the heads of shops. The progress is great because there is no qualified force. There were cases when old workers from former kitchens came to a factory-kitchen; they could not work. It is clear that they have not worked at such an organized factory. Everyone works in a handicraft way; they are not accustomed to labor discipline like in a factory; they have never worked in a factory. We serve Narva Zastava in the full sense and almost the entire Narva region. If we count all the diners, then $85 \%$ falls on the share of the factory-kitchen. The Lenin Factory and Canteen likely feed the rest. The factory really feeds in a modern way. For example, food arrives. The factory has an inspector and a merchandiser who accept products. If the product is good, it is left in the pantry; it is sent back if it is unusable. The one that raises doubts is immediately sent to the laboratory located here, in the factory. It is the first stage. The second stage is when the product arrives at the workshop for processing. Here again, the inspector and the merchandiser examine it. Then, when everything has already been made, the product is again viewed by the inspector before sending it to the branches. In the buffet, the cutlet is also inspected by our inspectors. At the Putilov plant, three people sit, they check whether the product is good or bad. Inspectors taste, examine the color and smell. Every factory worker must undergo a medical examination every month; otherwise, they will not be allowed to work. If, for some reason, they do not go, then they are removed from work even if it is the head of the production. We have two show- 


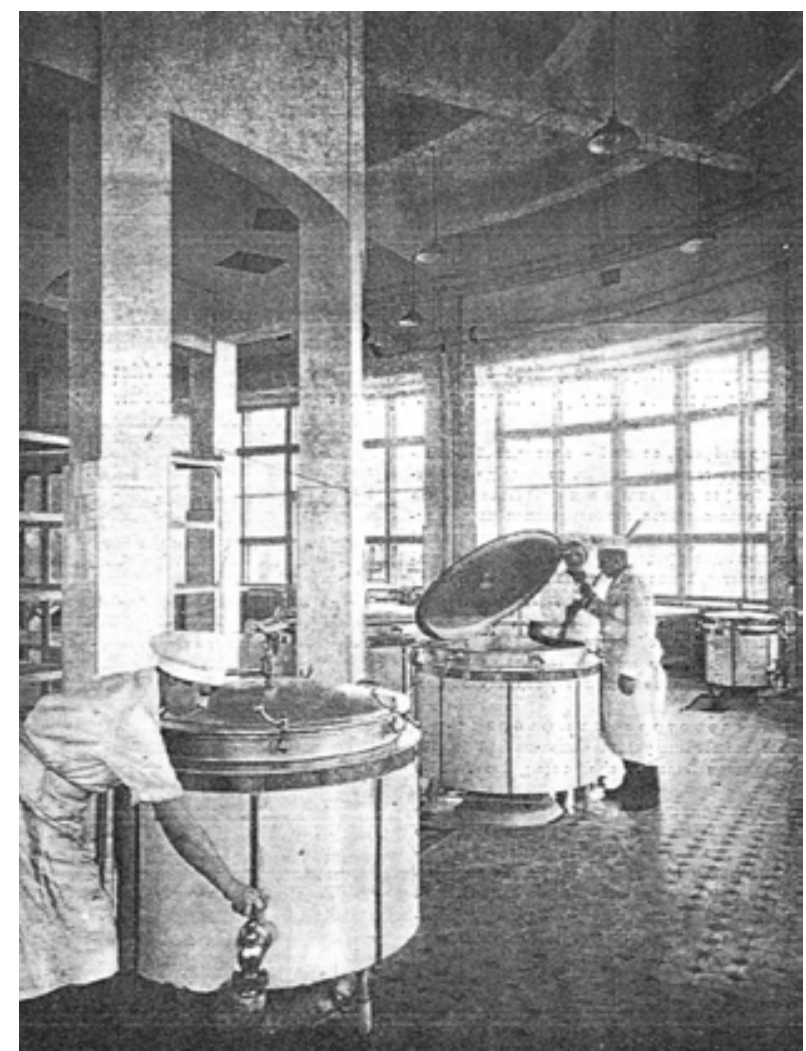

"Cookroom. Leningrad Factory-Kitchens", Architecture of the USSR, 1933, no. 2, 20

ers - for men and women. We believe that our factory is mainly a workshop of the Putilov plant. If we fail to provide lunch on time, it means that the main workshop of the Putilov plant has not fulfilled the program. <...> Here, it is a responsible and new job. Running a canteen is one thing, but working in such a huge one is another. Fifty-two thousand food units! And the food unit is the first and second meals, and if there are sandwiches, it is about fifteen or twenty. A food unit is not a single dish but is determined by its calorie content. And you cannot give all workers the same meal. Special ones are needed in a hot workshop, as well as in a harmful one. Our dispatch is the heart of the factory. If the dispatch does not work well, the whole factory will work badly. The first shift on the dispatch accepts the product and releases it down to the site. The second shift delivers all the products to the branches, and the third one collects all the containers from the canteens to the factory because we have a limited number of containers. If we do not collect all the containers today, there is nothing to work with tomorrow". [5]

A devastating critical article published on September 7, 1931, in the Leningrad cooperators' newspaper contradicts the worker's enthusiastic description. [3]. "The Narva Factory-Kitchen was founded by cooperation with excellent intentions. It meant improving nutrition, freeing the working family from the kitchen, and many more good things. 4.2 million rubles were spent on its construction and equipment, and instead of the factory, there was a public catering palace. The factory began to serve thousands, tens of thousands of workers but very soon, it turned out that, at the behest of the factory managers, everything has been left on its own, which has already been going on for ten months. Unsanitary conditions are rampant: the floors are dirty, the tables are dirty, the walls of the beautiful halls are covered with advertisements. The cleaning of the tables after dinner is delayed, and everyone who sits at the table finds it dirty. Dishes are available in sufficient quantities in the pantries, and tea is dispensed from the buffet without saucers in glasses. Apparently, forks and knives are luxuries in Leningrad cooperators' minds, and they are not in the canteens, including in the Narva one. The supply of food to the factory is unacceptably inadequate.

Amid the vegetable season, when hundreds of wagons of vegetables lay in the LSPO warehouse, the factory was still making cereal soups, porridges, and cutlets. Vegetables were barely visible on the menu. However, on the other hand, the factory saved up such quantities of caviar and sweets that it had to do something other than its own business - the wholesale of caviar. In the case of transport difficulties, about 5-6 tons of bread is imported to the factory every day. Half of it is cut into halves and is taken out from there to Krasny Putilovets as if cutting bread is so tricky that it is impossible to perform this operation on Krasny Putilovets. The storage of products in the workshops is the sore spot in the factory. Until now, there is no cold equipment in the workshops, and the masters attribute any damage to this. The number of defects and harm reached 22,220 rubles in the first half of 1931. The factory menu is exceptionally monotonous. Everything is repeated from day to day: sour cabbage soup, sour cabbage soup, soup, and then porridge, goulash, cutlets, goulash, porridge, cutlets... The taste of food can be imagined if you look at the quality certificates and the sod return size. Food delivery is also not always timely. In general, the return for various reasons reached the amount of 129,807 rubles in half a year. The selection of workers at the canteens in the factory-kitchen is carried out frivolously, and no one has a headache about this. As a result, in 9 months, with the blessing of Comrade Salayav, about 40,000 rubles have been spent at the factory. One interesting episode: the storekeeper of the Moscow-Narva House of Cul- 
ture, Nemchinov, wishing to profit, concocted an act for the loss of cakes, breaking of dishes, underfilling of bottles, etc. It turned out that in 1.5 months, rats ate 342 cakes, and 865 bottles without fruit water as well as 167 broken ones were delivered to the buffet. Instructor Reize imposed a "confirm" resolution, and Deputy Head Belyaev, as if the owner, ordered the branches to write off the cost of all this at 531 rubles. There were many such cases. Catering is no longer in cooperative hands. The state took it under its jurisdiction. Starting such a responsible business, the leaders of the future state association of public catering should begin by cleansing the factory of decayed leaders and then tackle the implementation of the Central Committee's instructions on public catering promulgated on August 19, 1931". [3].

The above documents, different in genre and assessment of what was happening, make it possible to present the reality of the first years of the factory-kitchen: its construction and the beginning of work and are evidence of the practice of implementing architectural projects of the 1930s.

\section{REFERENCES}

1. Krasnaya Gazetta, 03.10. 1930.

2. Leningradskaya Pravda, 20.09.1930.

3. "At the Narva Factory-Kitchen", Cooperative newspaper, September 7, 1931.

4. Report of the Narva District Council from 01.01.29 to 01.10.30; Leningrad, 1930, Stepanov. Putilov workshop - Narva Factory-Kitchen, Four Generations. Narvskaya Zastava. Leningrad, 1933.
5. TsGA NTD (Central State Archive of Scientific and Technical Documentation), fund 192, in. 3-1, f. 9951.

6. TsGA NTD, fund 192, in. 3-1, f. 9834.

7. TsGA SPB (St.Petersburg Central State Archive), fund 4370, in. 2, f. 1048.

8. 
Рафаэль Маратович Даянов

преподаватель кафедры архитектуры Санкт-Петербургского государственного академического института живописи, скульптуры и архитектуры имени И.Е. Репина,

архитектор-реставратор высшей категории,

Заслуженный строитель Российской Федерации,

Почётный архитектор РФ,

Почётный реставратор Санкт-Петербурга; директор Архитектурного бюро «Литейная часть - 91»,

e-mail: rafdayanov@mail.ru

Санкт-Петербург, Россия

Orcid 0000-0002-8950-0698

Анна Михайловна Залманзон

научный сотрудник Балтийской реставрационной коллегии;

e-mail: zalmanzon@mail.ru

Санкт-Петербург, Россия

Orcid 0000-0002-5099-4301

\section{СТРОИТЕЛЬСТВО КИРОВСКОГО УНИВЕРМАГА И ФАБРИКИ-КУХНИ}

\section{В ВОСПОМИНАНИЯХ И ДОКУМЕНТАХ}

\begin{abstract}
Аннотация: В настоящей статье излагается история строительства Нарвской фабрики-кухни в конце 1920-х - начале 1930-х гг. В 1920-1930 гг. в СССР принято решение о повсеместном строительстве фабрик-кухонь, которые должны были стать основой государственной системы общественного питания. В Ленинграде было решено построить четыре фабрики-кухни, в том числе Нарвскую, которая должна была иметь общее здание с универмагом (позднее Кировский универмаг). Был объявлен конкурс на создание проекта здания фабрики-кухни. В статье описывается проект фабрики-кухни, выигравший конкурс. Авторами проекта, представляющего собой образец конструктивизма, были четыре архитектора. Со временем идея фабрик-кухонь оказалась несостоятельной, и Нарвская фабрика-кухня была закрыта. На длительное время перестал работать и Кировский универмаг, который в начале 2000х решили реконструировать. При подготовке проекта реконструкции Кировского универмага была проведена исследовательская работа по выявлению проектных материалов и документов по истории здания Нарвской фабрики-кухни и универмага. Кроме большого количества графических изображений, авторы статьи обнаружили интересные факты, касающиеся хода строительства и первых лет работы фабрики-кухни. Найденные документы: протоколы, отчеты, критические заметки и воспоминания участника событий освещают ход строительства и работы фабрики-кухни с разных углов зрения - официальных материалов (текстов пояснительных записок к проектной документа-
\end{abstract}

ции, публикаций в официальной прессе, протоколов совещаний, актов инспектирования строительства) и личных оценок различных фактов, связанных с Невской фабрикой-кухней (воспоминания современников, рабочих, принимавших участие в строительных работах и дальнейшей эксплуатации предприятия). Документы также позволили воспроизвести реалии производственного процесса 1920-х-1930-х гг., например, социалистическое соревнование, ударничество, штурмовщину. Выявлено, что строительные работы осуществлялись при фактическом отсутствии чертежей. Кроме того, систематически нарушалась координация работ. Созданная картина показывает низкий уровень организации работ, который стал причиной многочисленных недоделок и низкого качества строительства. Это, в свою очередь, послужило одной из причин проблем при эксплуатации фабрики-кухни. Статья также отмечает на основе обнаруженных документов и собственно нарушения эксплуатационного характера: несоблюдение санитарно-гигиенического режима, однообразное меню столовой, низкое качество блюд. Документы также сообщают о хозяйственно-экономических нарушениях. В дальнейшем в силу ряда причин себя дискредитировала и сама идея фабрики-кухни. В настоящее время здание Кировского универмага реконструировано и эксплуатируется.

Ключевые слова: фабрика-кухня Нарвского района, Кировский универмаг, организация строительства, история СССР, 1930 гг. 
При подготовке проекта реконструкции Кировского универмага была проведена исследовательская работа по выявлению проектных материалов и документов по истории Нарвской фабрики-кухни и универмага. Кроме большого количества графических изображений, авторы исторической справки обнаружили интересные факты о ходе строительства и первых годах работы фабрики-кухни. Найденные документы: протоколы, отчеты, критические заметки и воспоминания участника событий освещают процесс строительства и работы фабрики-кухни с разных углов зрения - официальных данных и эмоциональной оценки происходящего. Мы приводим их в одной публикации, чтобы как можно точнее воспроизвести историю строительства Кировского универмага и фабрики-кухни, связанные с ним события и эмоциональную атмосферу.

В 1928 г. в Ленинграде был объявлен конкурс на проектирование фабрик-кухонь. По условиям конкурса они должны были снабжать готовыми обедами промышленные предприятия и являться частью общественных центров районов (Санкт-Петербург. Петроград. Ленинград. Энциклопедический справочник. Л., 1992, с. 635). Конкурс выиграли молодые архитекторы: А.К. Барутчев (1904-1976), И.А. Гильтер (1902-1976), И.А. Меерзон (1900-1941), Я.О. Рубанчик (1889-1948), которым и было поручено проектирование 4-х районных фабрик-кухонь.

Необходимость строительства в рабочих районах предприятий общественного питания с большой производительной мощностью диктовалась бурным восстановлением и развитием здесь производственных предприятий в конце 1920x - начале 1930-х гг. Многократно выросшее за десятилетие 1920-х гг. население окраин необходимо было обеспечить продуктами питания. Срочной мерой и наиболее рациональной схемой снабжения в тех условиях и явились централизованная поставка и обработка продуктов. До появления Нарвской фабрики-кухни в Нарвском районе действовала Ленинская фабрика-кухня, находившаяся, по-видимому, в приспособленном для этой функции здании.

К началу строительства Нарвской фабрики-кухни здание Ленинской фабрики-кухни находилось в аварийном состоянии, ее планировалось остановить. [5]

Согласно проектному заданию, проект Московско-Нарвской фабрики-кухни предполагал объединение в одном здании фабрики-кухни и районного универмага. Место, отведенное для строительства, находилось в административном и общественном центре Московско-Нарвского района, что представлялось удобным для функционирования фабрики-кухни и универмага: посещений столовой и магазина рабочими и развозки обедов на предприятия района. (Рис. 1. Нарвская площадь в 1920-х гг. Форзац книги: «Четыре поколения. Нарвская застава». Л, 1933) К разработке технологии производственного процесса были привлечены специалисты - работники общественного питания. Размеры помещений, их расположение разрабатывались в сотрудничестве с комиссией специалистов, созданной Ленинградским областным потребительским союзом Нарпит. [8]

Оборудование проектировалось в соответствии с нормами, разработанными Нарпитом для фабрик-кухонь, производительностью 12 тыс. обедов в день.

К марту 1929 г. проектирование Нарвской фабрики-кухни было закончено. Этим временем датированы проектные материалы, направленные проектирующей организацией на утверждение в Ленинградский отдел охраны труда. (Рис. 2. Пояснительная записка к проекту строительства фабрики-кухни Московско-Нарвского района, ЦГА НТД, ф. 193, о. 3-1, д. 5832, л. 7)

Архитектура Кировского универмага и фабрики-кухни выдержана в стиле конструктивизма. В компоновке объемов и плана отразилась конструктивистская эстетика: сочетание различных по форме и высоте объемов, асимметричная плановая композиция, динамичная выразительность облика, достигаемая с помощью сдвижки масс и контрастного оформления фасадов. В архитектуре фабрики-кухни использованы многочисленные приемы, свойственные архитектуре конструктивизма, и имеющие широкий круг аналогов в близких по времени постройках мастеров конструктивизма.

В конструкции здания фабрики-кухни и универмага применена каркасная система из монолитных железобетонных блоков. В работе над проектом здания со сложной функцией, включающей развитый производственный процесс, торговлю и общественное питание, плановые решения принимались на основании анализа схем функциональных процессов. Планировка здания продумана таким образом, что схемы 
функциональных процессов внутри него не пересекались. (Рис. 3. Проект фабрики-кухни Московско-Нарвского района. Ситуационный план ЦГА НТД, ф. 193, о. 3-1, д. 5832, л. 76) В апреле 1929 г. проект был утвержден. [4]

Архитекторы предполагали, что на фабрике-кухне будет работать 190 чел. По мере продвижения строительства, запроектированные мощности и нормы фабрики-кухни стали фальсифицироваться в прессе. «Красная газета» в 1930 г. называла запроектированную мощность фабрики-кухни в 35-40 тыс. обедов в день. Количество работников фабрики, по сообщению газеты, будет равняться 1500 чел. [1]

К строительным работам приступили в мае. [5] По указаниям руководящих районных организаций здание должно было быть построено в кратчайший срок. Темпы строительства ускоряли методом соцсоревнования и ударничества: рабочие бригады перерабатывали, работали сутками. Когда рабочих стало не хватать, были созданы 3 женские строительные бригады. Архитектурно-строительные рабочие чертежи и чертежи оборудования разрабатывались одновременно со строительством. Часто темпы строительства опережали сдачу чертежей. Иногда строители сами принимали ответственные решения, касающиеся конструкций здания и оборудования. [5] Оснащение оборудованием производились в ходе сооружения здания. Зимой работы проводились в тепляках с временным отоплением, проведенным от одного из соседних заводов. [5] По утвержденным срокам фабрика должна была быть закончена к 1 мая 1930. В июле 1929 г-на строительной площадке были выполнены земляные и бетонные работы, шли работы по забивке свай, - было забито 690 8-метровых свай, и 210 - 11-метровых, что составляло около 27\% свайных работ. Строители отставали от запланированного графика на 2 недели.

Строительные чертежи не успевали поступать на строительную площадку. В акте осмотра стройки говорилось: «В случае недоставки на место работ рабочих чертежей в течение ближайших 4-х дней, по корпусам IIA, IB, IV подвальных этажей, а также по корпусам I A и III вторых этажей, опоздание против календарного плана может еще более увеличиться. Организация работ поставлена удовлетворительно. <...> На стройке имеется рационализаторская ячейка, проводится внутри стройки социалистическое соревнова- ние между отдельными группами рабочих, как и между техперсоналом. Работы ведутся в 2 смены по свайной бойке, земляным работам, арматурам и частично по бетонным работам. Общее качество работ удовлетворительное, отступлений от утвержденного УСК проекта не замечено». [7]

В 1930 г. запаздывание в разработке рабочих чертежей продолжалось. Газета «Ленинградская правда» 25.03.1930 г. опубликовала заметку «Чертежи врут», в которой описывала трудности строительства фабрики-кухни и несогласованность действий проектировщиков и строителей. Для проверки фактов, изложенных в газете, 4 апреля 1930 г. состоялось обследование строительства комиссией. Комиссия подтвердила факты, изложенные в газете, и пришла к заключению, что срок сдачи к 1 мая 1930 г. упущен. [6] В акте, составленном комиссией, описаны ситуации, при которых воплощение строителями архитектурных проектов затруднялось из-за путаницы с рабочими и конструктивными чертежами: «Штукатурные работы, произведенные на значительной плоскости стен и потолков, являются ныне ненужными, ввиду использования пространства под потолками для укладки труб вентиляции, занимаемого ныне фальшивым потолком, штукатурка коего требуется ныне вновь. Штукатурка в небольшой части стен сбивается, ввиду решения заменить ее плитками, облицовка коими производится. Все вышеуказанные переделки, недоделки и изменения в работах и тому подобное объясняется отсутствием общей увязки основного проекта с проектами коренных санитарных оборудований и деталей, которых при производстве основных работ совершенно не имелось. Отсутствие чертежей на санитарное оборудование при ведении работы вчерне повлекло все описанные переделки и повлечет неминуемо в дальнейшем в тех размерах, какие необходимы для завершения оборудования. ...Обращается внимание администрации постройки на кривизну вертикальных стоек металлических переплетов в фасадных проемах, что может вызвать несовпадение плоскости стекла с гнездами. Тоже указывается на недостаточность уклона и отверстий отвода воды на балконе». [6] Комиссия выявила, что отставание в сроках работ вызвано недопоставкой чертежей на стройку: «Именно массовая переделка, связанная с установкой оборудования имеет место. Это делается не потому, что чертежи врут, а надо сказать, что чертежей совсем не 
было, когда делали здание вчерне». [7]. При осмотре строительства начальником ЛОУСК 11-12 июля 1930 г. также выявлено отставание в сроках и низкое качество работ. В частности, в акте осмотра отмечались: «...быстрый темп работ за счет их качества (плохая внутренняя штукатурка, недоброкачественная кровля, прогибы железобетонных конструкций». [7]

Новым сроком сдачи фабрики-кухни назначена дата 15 сентября 1930 г. [2] 20 сентября 1930 г. газета «Ленинградская правда» сообщила, что в этот день Нарвская фабрика-кухня начинала снабжать горячими обедами предприятие, а 25 сентября состоится официальное открытие фабрики-кухни. (Рис. 4. Нарвская площадь в 1930х гг. Форзац книги: «Четыре поколения. Нарвская застава». Л, 1933)

Официальные документы о ходе строительства фабрики-кухни дополняют живые воспоминания, которые оставил участник стройки, позднее - рабочий фабрики-кухни Степанов: «...в апреле 1929 года попал на постройку фабрики-кухни. Вся работа протекала под наблюдением инженера Джорогова. В апреле мы начали подготовлять сваи, по проекту - восьмиметровые. Забили свай около тысячи. Испытали, выдержат ли они такое массивное здание (фабрика строилась на реке Таракановке, место здесь жидкое, и сваи шли в землю от одного удара, от силы тяжести). Так вот испытали одну из свай, оказалось, что сваи негодные: нужны были одиннадцатиметровые сваи. Началась снова работа по их изготовлению. Эти сваи вполне могут выдержать весь массив здания. Общественные организации Нарвского района требовали постройки фабрики в кратчайший срок. К этому времени стала сдавать Ленинская фабрика-кухня. Там пошли трещины, ее нужно было остановить. Она обслуживала два гиганта - «Красный путиловец» и «Треугольник». Нужно было развить соцсоревнование и ударничество, и со второго корпуса оно начало проводиться в жизнь. Началось оно между бригадами, и вот в это время организовалась первая комсомольская бригада. Нас было немного, человек двенадцать. Окружили нас нехорошим мнением! Всегда говорили, что лучшую работу получает комсомольская бригада. Когда все корпуса были готовы, а пятый отстал, мы специально взялись за него и вытянули комсомольской бригадой. Нам, комсомольской бригаде, приходилось каждый вечер перерабатывать три-четыре часа. Мы с време- нем не считались. Секретарь партячейки говорил: сегодня остаемся, и оставались. На всех стройках зимой заканчивались работы, и вообще строительство считалось сезонной работой, а на фабрике-кухне как раз наоборот - работа зимой не уменьшилась, а еще увеличилась. Провели отопление с соседнего завода, и здесь, внутри уже, проходила работа по оборудованию здания. В 1930 году стало выявляться, что рабсилы недостаточно. Были организованы специально три женские бригады, которые работали наравне с мужчинами по возведению стен. Не было специальности, где 6 не участвовали женщины. Арматурщики - женщины, бетонщики - женщины. Комсомольцы воевали за темпы. Был тут Григорий Абрамович Изерсон, помощник прораба, техник. Парень дневал и ночевал тут, болел за фабрику. Парень простой, а умел работать. Были случаи, ждешь чертежей, чертежей нет. Взять хотя бы - нефтяной бак. Нужно пускать плиту, а бак не готов. Он приходит ко мне и говорит: «Ну, давай, Степанов, спроектируем сами, потому что чертежей нет, фабрику нельзя задерживать». Здесь мы часов пять-шесть просидели и составили чертеж. Он мне говорит о сопротивлении материалов, а я конструирую, черчу. Потом чертеж пришел и сошелся с нашим. Так же и лестница. Тоже чертежей не присылают. Думаем, - фабрика построится, а парадной лестницы не надо. Пришлось нам самим сделать так, чтобы лестница выдержала. Для ночного контроля учредили на стройке дежурства. Легкой кавалерии нашего коллектива приходилось дневать и ночевать. Были случаи, что специально там, где курили, подливали бензин. Много было случаев. Или, когда универмаг открывался, кто-то принес керосин. Кто принес керосин и зачем - неизвестно. А вокруг раскинуты стружки. Работали круглые сутки, чтоб покончить с фабрикой в срок. Правда, срока мы не выдержали. Срок был -1 мая 1930 года. Мы же открылись 1 октября». [5]

3 октября 1930 г. «Красная газета» сообщила, что 1 октября 1930 г. на Нарвской фабрике-кухне пущено в ход варочное оборудование и дан первый «пробный» обед. [1] В этот день был дан первый обед рабочим и служащим, строившим фабрику. (Рис. 5. Варочный цех. Фабрики-кухни Ленинграда //Архитектура СССР. 1933. № 2. С. 20) Однако здание не было полностью готово к эксплуатации. Документы свидетельствуют о том, что в октябре 1930 г. продолжался монтаж инженер- 
ных систем. 12-16 октября 1930 г. был «произведен осмотр производственных помещений на предмет определения готовности к пуску», который установил, что: «помещения к эксплуатации не готовы. Чертежи по водоснабжению, электроснабжению, вентиляции, комиссии не представлены». Универмаг был открыт весной 1931 г.

В сентябре 1931 г. Московско-Нарвская фабрика-кухня перешла из ведения ЛСПО к государству. Запланированная мощность фабрики-кухни в 15 тыс. обедов в день была достигнута за период до 1931 г., большая часть населения Московско-Нарвского района получала обеды из районной фабрики-кухни. Крупнейшими потребителями были Путиловский завод, Северная верфь и завод им. Молотова. Фабрика-кухня вывозила горячие обеды в свои филиалы - буфеты на предприятиях. Рабочие ближайших к фабрике-кухне заводов обедали в зале при фабрике-кухне. Здесь же получали обеды дети из ближайших школ и детских садов.

Строитель и рабочий фабрики-кухни так описывает ее работу в начале 1930-х гг.: «1 октября был дан первый обед рабочим и служащим, которые строили фабрику, и с 1 октября стали снабжать пять буфетов. Когда фабрика была пущена в ход, еще некоторые цеха не приступили к работе. Не было машин. Были случаи, вода не проходила. Двор, от которого должны все обеды развозиться по фабрикам, был завален строительным мусором. Не было экспедиционной площадки, и подчас подводам, которые выезжали с обедами на Путиловский завод, нужно было миновать целый ворох мусора. Не было отдельной лестницы, были непорядки в работе лифтов. Универмаг был отделан к 1 мая 1931 года, потому что это было не так срочно. Когда фабрика строилась, она была рассчитана на пятнадцать тысяч пищевых единиц. Начала она развиваться, дошла до пятнадцати тысяч, пошла дальше. В первых числах января 1931 года Ленинская фабрика остановилась. Нашей фабрике пришлось забрать и ту норму, которую кормила Ленинская фабрика. Тысяч тридцать пять мы стали уже обслуживать. После того как Ленинскую фабрику отремонтировали, мы все-таки темпов не сбавили. Основным потребителем является Путиловский завод. На Путиловском заводе нет ни одного цеха, где бы не было нашего буфета. Мы снабжаем их продуктами, инвентарем и рабсилой. Самый буфет и оборудование делает администрация завода. Вторым основным потребителем является Северная верфь. Третьим - завод им. Молотова и потом мелкие заводики Нарвского района, за исключением «Красного треугольника» и фабрики «Равенство», которых кормит Ленинская фабрика-кухня. Фабрика работает без перерыва. Нет ни свободных дней, ни праздников. И 7 ноября фабрика не отдыхает. Если не работает горячий цех, то работает холодный. Нет ни одной минутки, чтобы фабрика отдыхала. Доставляем на место пищу в термосах в горячем виде, но нельзя скрывать, что, если пища налита в термос в двенадцать часов ночи, она может держать теплоту до шести-семи часов, - остывает. Вообще фабрика рассчитана на полуфабрикаты, т.е. на месте должна быть кухня, у нас же только заготовки. Сейчас есть еще новый способ, который изобрел наш лаборант, доктор Углов, с таким расчетом, чтоб возить на места, в буфеты концентрированный суп, т.е. он в сгущенном положении возится туда: привезя на место, его разбавляют горячим кипятком, и получается по калорийности и по всему лучший суп. Один зал закреплен за теми заводами и организациями, которые расположены ближе к фабрике, чтобы не делать там специального буфета, чтобы рабочие во время перерыва могли прийти сюда и покушать. Этот зал внизу. Второй зал - зеленый зал, он называется поблюдным залом. Здесь по более дорогой цене может обедать каждый, кто захочет. Третий зал (в третьем этаже) называется розовым залом, детский зал. Мы обслуживаем детей Нарвского районо. До двух часов идут специально ученики школ. Те школы, которые находятся поблизости, мы кормим здесь, при фабрике; в организованном порядке они приходят сюда со старшими группами, садятся за столы, и мы их обслуживаем. С двух часов кормим детей, которые не обучаются еще в школе. Школы Нарвского района, которые находятся далеко от фабрики, мы кормим на местах. Все школы нашего района обслуживаем мы, и не только школы, но и дошкольный возраст, - снабжаем очаги при жактах (жилищно-арендное кооперативное товарищество в СССР до 1937 г. - прим. авт.). Четвертый зал, рядом с коллективом комсомола, - служебная столовая, здесь имеют право есть те, которые работают на фабрике, за исключением тех, кто работает на периферии, в буфетах нашего района. В феврале 1932 г. у нас было 1750 рабочих, совместно с периферией Нарвского района, со всеми буфетами. В штат нашей фабрики вхо- 
дит и бригадное ученичество. У нас человек сорок учеников, которые здесь подготовляются на будущих рабочих. Рабочие фабрики тоже посещают курсы. Здесь есть комната поварского ученичества и по повышению квалификации. Если взять этот год, то у нас рядовые работники дошли уже до заведующих цехами. Продвижение большое, потому что квалифицированной силы нет. Были случаи, когда приходили старые работники с бывших кухонь на фабрику-кухню, они не могли работать. Понятно, они еще на такой организованной фабрике не работали, всякий работает по-кустарному, трудовой дисциплины, как на фабрике, не имеет, по-фабричному никогда не работали. Мы обслуживаем Нарвскую Заставу в полном смысле и почти весь Нарвский район. Если подсчитать всех обедающих, то 85\% падает на долю фабрики-кухни. Остальных, пожалуй, кормит Ленинская фабрика и столовая. Фабрика действительно по-современному кормит. Например, поступают продукты. На фабрике есть бракер и товаровед, которые принимают продукты. Если продукт годен, оставляют в кладовой, негоден, - отправляют обратно. Тот, который внушает сомнения, сразу же в лабораторию, находящуюся здесь же, на фабрике. Это - первый этап. Второй этап, - когда продукт поступает в цех на обработку. Тут опять же бракер и товаровед его осматривают. Потом, когда уже все изготовлено, при отправке на филиалы, продукт опять просматривается браковщиком. В буфете котлета тоже бракуется нашими браковщиками. На Путиловском заводе сидят специально три человека, они проверяют, годный или негодный товар. Бракер пробует на вкус, на цвет, на запах. Каждый работник фабрики обязан пройти каждый месяц медицинскую комиссию, иначе он не будет допущен к работе. Если почему-то он не идет, то снимается с работы, будь то хоть заведующий производством. Есть у нас два душа - мужской и женский. Мы считаем, что наша фабрика является в основном цехом Путиловского завода. Если мы не сумеем вовремя дать обед, то это значит, что основной цех Путиловского завода не выполнил программу. <...> Здесь - ответственная и новая работа. Заведовать столовой - это одно, а работать в такой громадине - дело другое. Пятьдесят две тысячи пищевых единиц! А пищевая единица - это первое и второе, а если бутерброды, так это штук пятнадцать-двадцать. Пищевая единица не является одним блюдом, а опреде- ляется по калорийности. И нельзя же дать всем рабочим одинаковые обеды. В горячий цех нужны специальные, во вредный цех - тоже. Экспедиция у нас - сердце фабрики. Если экспедиция будет плохо работать, будет работать скверно вся фабрика. Первая смена в экспедиции принимает продукт и отпускает на площадку вниз. Вторая смена выбрасывает весь продукт на филиалы, и третья собирает всю тару из буфетов на фабрику, потому что тары у нас ограниченное количество. Если мы сегодня всю тару не соберем, на завтрашний день работать не с чем». [5]

Противоречит восторженному описанию работника разгромная критическая статья, опубликованная 7 сентября 1931 г. в газете ленинградских кооператоров. [3] «Нарвская фабрика-кухня заложена была кооперацией с чрезвычайно благими намерениями. Имелось в виду улучшение питания, освобождение рабочей семьи от кухни и еще много хорошего. 4,2 млн. рублей было истрачено на ее постройку и оборудование, и вместо фабрики вышел дворец общественного питания. Фабрика начала обслуживать тысячи, десятки тысяч рабочих, но очень скоро оказалось, что по воле руководителей фабрики, все было предоставлено самотеку, продолжающемуся вот уже 10 мес. Свирепствует антисанитария: полы грязные, столы грязные, стены прекрасных зал завешиваются объявлениями. Уборка столов после обедающих затягивается, и каждый садящийся за столик находит его грязным. Посуда имеется в достаточном количестве в кладовых, а из буфета чай отпускается без блюдец в бокалах. Вилки и ножи, видимо, роскошь в представлении ленинградских кооператоров, и в столовых, в том числе и в Нарвской, их нет. Снабжение фабрики продуктами велось недопустимо скверно. В самый разгар овощного сезона, когда на складе ЛСПО лежали сотни вагонов овощей, фабрика все еще варила крупяные супы, каши и котлеты. В меню овощи едва были заметны. Но зато фабрика позапасла икры и конфет в таком количестве, что ей пришлось заняться не своим делом - оптовой продажей икры. При транспортных затруднениях на фабрику ежедневно завозятся около 5-6 тонн хлеба, который на половину в разрезанном виде вывозится оттуда на Красный Путиловец, как будто резка хлеба настолько сложна, что нельзя на Красном Путиловце производить эту операцию. Больное место на фабрике - хранение продуктов в цехах. В последних нет до сего времени 
холодного оборудования, и мастера всякую порчу относят на этот счет. Сумма брака и порчи на первое полугодие 1931 года достигает 22220 руб. Меню на фабрике крайне однообразное. Изо дня в день повторяются щи кислые, кислые щи, суп, а затем каша, гуляш, котлеты, гуляш каша, котлеты... Вкус пищи можно себе представить, если посмотреть акты о качестве, размеры возврата пищи. Доставка пищи тоже не всегда своевременная. В общем, возврат по разным причинам достиг за полугодие суммы в 129807 руб. Подбор работников за буфетами на фабрике-кухне проводится легкомысленно, и ни у кого по этому поводу голова не болит. В результате за 9 мес. на фабрике с благословения тов. Салая растрачено около 40000 руб. Один интересный эпизод: кладовщик Московско-Нарвского дома культуры Немчинов, желая поживиться, состряпал акт на пропажу пирожных, бой посуды, недолив вод в бутылки и т.д. Оказалось, что за 1,5 мес. крысы съели 342 пирожных, в буфет пришло 865 буты- лок без фруктовых вод и 167 битых. Инструктор Рейзе наложил резолюцию «подтверждаю», а зам. зав. филиалами Беляев широкой рукой хозяина распорядился о списании стоимости всего этого в 531 руб. Таких случаев можно было привести немало. Общественное питание больше не в кооперативных руках. Государство приняло его в свое ведение. Начиная такое ответственное дело, руководители будущего государственного объединения общественного питания должны начать с очищения фабрики от загнивших руководителей, а затем уж энергично приняться за осуществление указаний ЦК по вопросам общественного питания, обнародованных 19.08. 1931 г». [3].

Приведенные документы, разные по жанру и оценке происходящего, вместе дают возможность представить реальность первых лет фабрики-кухни: ее строительства и начала работы, и являются свидетельством практики воплощения архитектурных проектов 1930-х годов.

\section{БИБЛИОГРАФИЯ}

1. Красная газета. - 03.10.1930.

2. Ленинградская правда. - 20.09.1930.

3. На нарвской фабрике-кухне // Кооперативная газета.ч - 07.09.1931.

4. Отчет Нарвского районного совета РК и КД с 01.01.29 по 01.10.30; Ленинград, 1930. Степанов. Путиловский цех - Нарвская фабрика-кухня // Четыре поколения. Нарвская застава. - Л., 1933.
5. ЦГА НТД (Центральный государственный архив научно-технической документации). Ф. 192. О. 3-1. Д. 9951.

6. ЦГА НТД. Ф. 192. О. 3-1. Д. 9834.

7. ЦГА СПБ. Ф.4370. О. 2. Д. 1048. 